\title{
Does financial inclusion increase financial resilience? Evidence from Bangladesh
}

Dr. A H M Belayeth Hussain

Centre for Research on Women \& Gender (KANITA)

Universiti Sains Malaysia (USM), Malaysia.

Email: belayeth@usm.my

Dr. Noraida Endut

Professor and Director

Centre for Research on Women \& Gender (KANITA)

Universiti Sains Malaysia (USM), Malaysia.

Email: idaman@usm.my

Dr. Sumonkanti Das

School of Business \& Economics

Maastricht University

Netherlands

Email: sumonkanti-sta@sust.edu

Mohammed Thanvir Ahmed Chowdhury

Department of Applied Sociology and Social Work

North East University Bangladesh

Email: thanvir@neub.edu.bd

Nadia Haque

Department of Sociology

Shahjalal University of Science \& Technology

Bangladesh

Email: nh.haque11@gmail.com

Sumena Sultana

Department of Sociology

Shahjalal University of Science \& Technology

Bangladesh

Email: sumena sultana $@$ yahoo.com

Khandaker Jafor Ahmed

Department of Geography, Environment and Population

The University of Adelaide

North Terrace, South Australia 5005.

Email: khandaker.ahmed@adelaide.edu 


\begin{abstract}
:
This study explores the impact of financial inclusions on financial resilience. In doing so, we utilize the World Bank's data on global financial inclusions. Our study confirms that the respondents with financial accounts are more resilient than those without accounts. The chances of being financially resilient are around 1.4 times higher for the account holders than their counterparts. We find a significant relationship between gender and financial resilience; males are 1.4 times more resilient than females when other covariates are considered in the regression model.
\end{abstract}

Key Words: Financial Inclusion, Financial Resilience, Bangladesh 


\section{Introduction:}

The importance of an inclusive financial system is widely known in development policy and is perceived with priority in many countries. It enables an efficient allocation of productive resources, creates access to appropriate financial services and can help to reduce the growth of informal sources of credit (Sharma, 2010). Financial inclusion is ensuring access to appropriate financial products and services to the people, regardless of their income level. At the primary level, the process starts with having a bank account, although for the study we demarcated financial inclusions as the combination of financial account penetrations, savings, and borrowings. On the other hand, financial exclusion is an inability of individuals, households or groups to access financial services in an appropriate form, misleads their entrance to a larger economic opportunity, and increases the risk of poverty.

Moving to a banking system can deliver an entry point into the formal financial system, which can lead to substantial increases in savings and the change to formal from informal savings. As per the Global Findex data (2014), 38 percent of adults remain unbanked around the world. Providing a regulatory framework favorable to expanding account ownership can lower or even eliminate obstacles to financial inclusions. The challenge in each circumstance is to design suitable financial products that meet the needs of the unbanked and make use of an account with ease and appropriateness.

In last few years, account ownership has been increased in every region in the globe; nonetheless, the growth was particularly robust in East Asia and the Pacific, South Asia, and Latin America and the Caribbean. Each country witnessed a growth in account penetration of more than 10 percent. This escalation was focused in account penetration in financial institutions everywhere except Sub-Saharan Africa, where digital financial (mobile banking) services promote overall account penetration from 24 percent in 2011 to 34 percent in 2014 (Global Findex database, 2014).

Financial inclusion is not an end in itself; rather it increases risk-taking behavior. When people have a safe place to save money and access to credit in need, they are in a better off to manage potential risks. To understand easily how people around the world are financially resilient, we need a country-specific dataset to analyze the key embedded factors in local circumstances. Turning to Bangladesh, the evidence of financially-resilient people is varied. In recent years, Bangladesh has been experiencing a great deal of development in the processes of financial inclusions. However, it is timely to examine what factors are responsible for making people financially resilient even though they have financial penetrations through various channels. Therefore, this study aims to inquire the effects of gender gap, education, and income on financial resilience considering specific factors of financial inclusion in ceteris paribus conditions. Before going into the analyses, for the ease of identifying the state of different factors in the processes of financial inclusions, we articulate relevant literature in questions.

\section{Status of financial inclusion in Bangladesh}

To tackle anticipated or unexpected crises, financial services that include a deposit or savings account plays a major role in various ways. In Bangladesh, Khalily et al. (2014) found that (from a cross-sectional survey) nearly 66 percent of households have any form of savings either in a bank, micro-finance institution or informal savings association. Among these households, about 13 percent have multiple accounts in diverse institutions. These people have better financial stability to lessen insecurity in any unforeseen condition. Han and Melecky (2013) 
studied the link between financial inclusion and financial resilience by using data from 90 countries globally. The authors perceived that financial inclusion, measured by broader access to and use of deposits, can shape the banks' deposit bases stronger in time of financial shocks. This eventually promotes the financial stability of countries, especially the middle-income nations. Similarly, Hannig and Jansen (2010) claimed that the inclusion of underprivileged and low-income people in the financial system will lead to an increment of credit and deposit bases which assist to improve local economic activities.

Considering a Bangladesh case, access to any type of savings is above 70 percent in the Khulna, Barisal, Rangpur, and Rajshahi divisions. However, families accessing a bank savings account is highest in Sylhet and Khulna whereas the other divisions have not significant access to a bank savings account. The financial sector of Bangladesh has seen new concepts in the last few years with a usage of ATM machines, credit card, debit card, mobile banking and 'Ten Taka' account. Among these services, mobile banking has experienced a sharp rise in popularity. Mobile banking does not require one to attend any bank branch and transactions can be carried out either through their own mobile bank account or by using another's bank account. Hence it is not only convenient for the poor but well-off individuals can also use the service (Khalily et al. 2014). It can be assumed that mobile banking plays a noteworthy role in the deepening of financial inclusion in Bangladesh.

\section{Gender and account penetration}

Based on the 2012 Global Findex data of 98 developing nations, Demirgüc-Kunt et al. (2013) highlighted a remarkable gender gap that prevails in terms of account ownership, formal saving and formal credit. They demonstrated many factors for such a gender gap (a lesser likelihood for women to be financially included) in the formal financial inclusion: a lack of financial knowledge and experience regarding business; a greater hurdle to present personal or collateral guarantees; a lack of documentation or because another member of the household belongs to an already opened account (Fungácová and Weill, 2015), and the husband's adverse credit record and vulnerabilities faced in the financial system. On a global scale, a significant level of gender gap prevails in overall account ownership (Allen et al. 2016). In contrast to this general scenario, a cross-country study demonstrates that women are less likely to get financing from a formal financial institution compared with men (Muravyev, Schafer, \& Talavera, 2009).

Demirguc-Kunt and Klapper (2012) observed that the gender gap is statistically significant in all regions, even when education, age, income, and country-level characteristics are being controlled. The Figure-1 demonstrates the gap in having an account between male and female in different regions in the world. We see that the proportion of having an account for a male is higher in all regions across the globe. However, the highest gender gap has been in South Asia where 25 percent female account penetrations stands against that of 41 percent males with financial accounts. The lowest gender gap prevails in Sub-Saharan Africa (differed by 5 percent) and East Asia and the Pacific (differed by 6 percent). However, around a 10 percent gender gap has been noticed in the Middle East and North Africa, Latin American and the Caribbean, Europe and Central Asia. The overall scenario of this gender gap highlights the variation of account ownership throughout the world by males and females. 


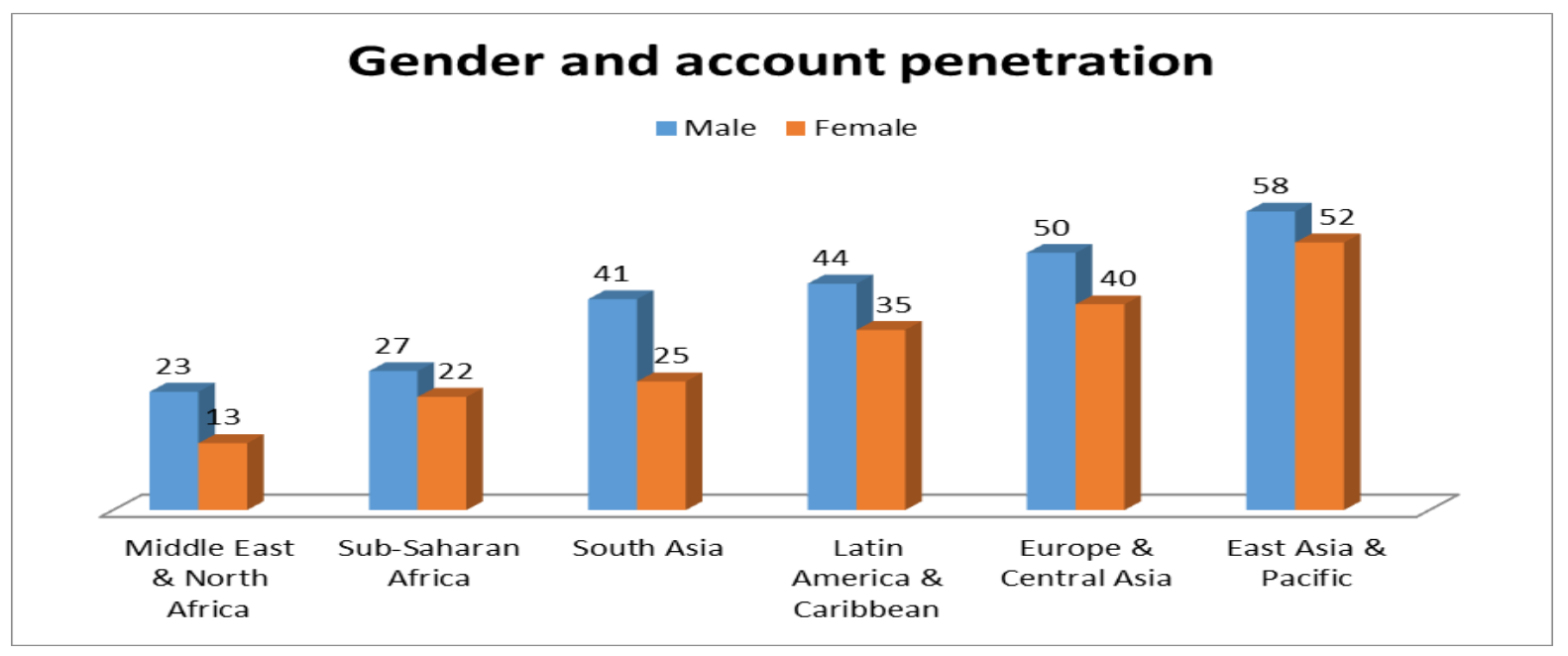

Figure-1 Gender and account penetration in different regions (Demirguc-Kunt and Klapper, 2012)

\section{Education, financial inclusions and financial resilience}

Allen et al. (2016) found there has been a greater likelihood of account ownership at a formal financial institution which is higher for richer, more educated, older, urban citizens, employed, married or separated individuals. Like Allen et al. (2016) and Fungácová and Weill (2015), Zins and Weill (2016) found that richer and more educated adults are more likely to be financially included. The seminal work on the impact of financial education by Bernheim et al. (2003) revealed that middle-aged individuals who attend a personal financial management course in high school save more than those who did not pursue the course. It can be said that having financial education helps people to be concerned with financial issues. Similarly, Hira and Loibl (2005) in a sample of employees of a large insurance company established that financial literacy improves workers' expectations about their future financial situation which will help them to be financially more resilient.

\section{Economic status and financial resilience}

Bruhn and Love (2014) in a study claimed that financial inclusions foster the income level of poor people and consequently there has been a greater likelihood to be employed which will affect their level of financial resilience in future. Poverty traps may appear for those who fail to include themselves in financial systems; as a result, their economic development gets hampered (Demirgüc-Kunt and Klapper, 2012) and their financial resilience declines as a byproduct of this underdevelopment. In these circumstances, however, whether rich or poor, they may adopt different strategies to cope with their financial vulnerabilities. For instance, Lianto (2007) in his study highlighted a few instruments adopted by low-income households in the Philippines to cope with the negative outcomes of risk events. Particularly, one strategy for the low-income households is 'informal on spot action' which delineates seeking instant help from relatives, friends, money lenders or selling their precious things. 


\begin{tabular}{|l|l|}
\hline Coping mechanism & Description \\
\hline 1. Informal, on-the-spot action & $\begin{array}{l}\text { Support from relatives, loans from money lenders, sale of } \\
\text { assets, e.g., livestock, farm animals. } \\
\text { 3. Institutional insurance schemes }\end{array}$ \\
$\begin{array}{l}\text { Support from rotating savings and credit associations, and other } \\
\text { informal schemes. }\end{array}$ \\
$\begin{array}{l}\text { Social security system, government service insurance system, } \\
\text { commercial insurers, if the households can access them. } \\
\text { Schemes developed by MFIs, mutual benefit associations, } \\
\text { cooperatives. }\end{array}$ \\
\end{tabular}

Lianto (2007)

\section{Saving pattern and financial resilience}

The savings and asset investments of poor households can play a crucial role in resilience building (Allan, 2002; Allen, et. al., 2010). Likewise, a study on extreme poor Marma households by Chakma (2013) found that local people in Chittagong hill tracts significantly changed their financial behaviors (regarding savings and investing) resulting from their involvement with the Village Savings and Loan Association (VSL) and their savings increased. It helped them to cope with illness and crisis moments of their savings. It enabled them not only to invest in income-generating activities for their subsistence but also mitigate the impacts of shock.

\section{Methods and materials:}

This study was done based on the World Bank's 2014 data on global financial inclusions known as the Findex database. This Findex database was collected in 2014 and published in 2015 . We considered 1000 representative samples randomly collected from civilian and non-institutionalized population aged 15 and above in Bangladesh. The two towering concepts in this study, financial inclusion and financial resilience, have been defined following the World Bank's operationalization. Financial inclusion combines financial account penetrations, savings, and borrowings. And, financial resilience is the condition of managing the risk of need for emergency funds in respondents' immediate days. To manoeuver the necessary variables and their analyses, we created three new variables from the existing database.

Because this study defines financial resilience as the possibility of coming up with emergency funds, this concept has been operationalized as how possible it is that a respondent could come up with 1/20 GNI per capita (in local currency) within the next month. Originally, the respondents had four possible answers: 'very possible', 'somewhat possible', 'not very possible' or 'not at all possible'. For our analyses and simple interpretation of outcomes, we defined our first new variable, financial resilience, as the combination of the possible answers of 'very possible' and 'somewhat possible'. We also separated respondents who answered 'not very possible' and 'not at all possible' as not being financially resilient.

To see the gender gap among financially included individuals and their status of being financially resilient, we created the second new variable labeled as 'financial account by gender.' We separated 'males with financial 
accounts', 'females with financial accounts', 'males without financial accounts' and 'females without financial accounts'. Employing this new variable, we wanted to see how likely a respondent (male or female) is able to come up with the emergency funds (financial resilience) with or without financial accounts.

For the third new variable, we narrowed down the variable educational status into two possible options: 'primary or less educated' and 'secondary or higher educated'. In the World Bank dataset, household economic status has been measured according to monthly household income in local currency before taxes which covers income from wages and salaries, remittances from family members living elsewhere, farming, and all other sources. From the income variable, the household economic condition is broadly classified into 5 groups according to quintiles of the income distribution. The groups are ordered as poorest (1st quintile) to richest (5th quintile). The other available variables in the data and considered in this study are given in Table 1 and Table 2 (Annex). In our analyses, depending on the literature we reviewed, we assumed four hypotheses in relation to financial inclusions and financial resilience in Bangladesh:

Hypothesis 1: Males are more likely to be financially included and resilient than females.

Hypothesis 2: Better educational attainments improve financial resilience.

Hypothesis 3: Richer people are financially more resilient than poorer.

Hypothesis 4: Better saving patterns indicates more financial resilience.

Two well-known statistical techniques, chi-square test and logistic regression analysis, have been employed to test the hypotheses. The chi-square test is used to test the hypothesis considering only the relevant factors seeing the financial resilience variable as four-level and two-level factor. To test whether the hypotheses are significant after controlling other factors, a multiple binary logistic model has been developed considering all the significant predictors of the financial resilience simultaneously. These two tests reveal univariate and multivariate relationships of the considered factors with the financial resilience.

\section{Results and Discussions:}

Table 1a (in the Annex) exemplifies the approximations of financial resilience indicators. Different conditions were used to test the strength of the results and address multi-loomed associations among the variables. Earlier in this paper, we defined financial resilience as the combination of the possible answers of 'very possible' and 'somewhat possible'. We also separated respondents who answered 'not very possible' and 'not at all possible' as not being financially resilient. The results derived from the chi-square test and binary logistic model shown in the Table $1 \mathrm{~b}$ indicate gender, education, financial inclusion, economic status and saving patterns that are significantly associated with financial resilience. The Logistic model has been found fitted well to the data based on the Hosemer-Lemeshow test (chi-square $=6.07, \mathrm{p}$-value $=0.64$ ). The area under the receiving operating curve (ROC) indicates that about 76\% (95\% CI: 73-79\%) individuals can be correctly classified according to their financial inclusion status. Based on the fitted Binary Logistic model (Table 1b), the results of the hypothesis tests are explained below: 


\section{Hypothesis 1: Males are more likely to be financially included and resilient than females}

Considering account penetrations, respondents with financial accounts (financial inclusions) are more resilient than who do not have such accounts; and the odds ratio of being financially resilient is about 1.4 times higher for the financial account holders than who do not have access to accounts (Table 1b). If we look at the gender dimension, we see there is a significant association between gender and financial resilience where the odds ratio of being financially resilient is about 1.4 times higher for the male compared to female respondents when the covariates remain the same. The percentage of males with financial accounts and resilience $(71.7 \%)$ is higher than the percentage of females with financial accounts and resilience (66.9\%). In the instances where males do not have financial accounts, they are still more resilient than females without accounts. We found $50.8 \%$ of males without financial accounts are resilient compared to $46.2 \%$ of females without financial accounts (Table 1b). Therefore, in both circumstances, we see females are less resilient than male respondents; but in intra-gender analysis, females with financial inclusion have more resilience control than females without financial inclusions. Hence, our first hypothesis regarding the gender identity, account penetrations, and financial resilience has been accepted.

Referring to individual's account penetration, the results have shown that respondents with financial inclusion are more resilient than those without financial inclusion. Various studies also support these findings, for instance, in a study based on micro-finance institutions, the International Labour Organization (2011) suggests that by being financially included (through micro-finance institutions) individuals can achieve savings, insurance and emergency loans which reduce their vulnerability and make them capable of managing various risks. Similarly, Ramji (2009) argues that a strong financial system makes poor households and small entrepreneurs independent of receiving supports from middlemen. That implies households seem more resilient through the process of financial inclusions.

Because of gender perspective, our results indicate that females are less resilient than male respondents. Likewise, Holloway et al. (2017) argue that women in the developing countries not only have their poor shares in account ownerships but also have a tiny formal saving experience. So, their ability to manage risk and smooth consumption in the face of shock or loss of income is also inadequate. Even in a study based in Thailand and Vietnam, Stephen et al. (2010) assert that female-headed households might be more vulnerable to poverty as they face higher risks and/or have fewer options to cope with various strategies.

\section{Hypothesis 2: Better educational attainments improve financial resilience}

In order to see the relations among the educational attainment, financial inclusions, and the financial resilience, we see in the Table 1a that there is a significant association between educational attainments and financial resilience. The respondents having at least secondary or higher education are more resilient than the respondents who completed primary education or below. Besides, the odds ratio indicates that the respondents with at least a secondary or higher level of education are about 2 (two) times more likely to be financially resilient compared to respondents with a primary level education or below (Table 1b). Therefore, we conclude that our second hypothesis about educational attainment and financial resilience has been accepted statistically. 
Regarding education, the results have shown that the respondents having at least secondary or higher education are more resilient than those who have only primary education or less than that. We find similar empirical results that support the findings of our study. For example, in a study based on African-American and Hispanic households, Lusardi and Mitchell (2006) found that the household heads with higher education can accumulate a larger amount of wealth and face any types of emergency difficulties because education makes them conscious to use and save money. In another study, Ramji (2009), found that besides financial inclusion, education is also necessary for financial resilience. According to his study, although all households of Gulbarga were financially included through government initiatives, they were at financial vulnerabilities due to lack of education and training. Similarly, the Alliance for Financial Inclusion (2016) states that education and awareness are the critical factors in the uptake of any financial service or product; hence reducing risk. Knowledge, skill and financial awareness help the borrowers assess their repayment capacity and prevent them from over-borrowing and overindebtedness (Kelegama and Tilakaranta, 2014). Therefore, financial education can improve levels of financial literacy, help individuals to overcome financial vulnerability caused by personal circumstances and potentially break down their psychological barriers (Atkinson \& Messy, 2013).

\section{Hypothesis 3: Richer people are financially more resilient than poorer}

Respondents those who have the richest economic status are more likely to be financially included than those who are in the poorest 20 percent. Referring to a household's economic status, the likelihood of being financially resilient escalates with the progress of household economic status. Results show that the higher the household's economic condition, the respondents are more likely to be financially resilient. Among the households, the richest 20 percent respondents are about 6 times more resilient compared to the poorest 20 percent respondents. The middle 20 percent of households are approximately 2.6 times more resilient than the poorest 20 percent households. The second 20 percent of households are 1.6 times likely to be more resilient than the poorest 20 percent households (Table -1b). These conclude that a household's economic status is found as a significant indicator of the financial resilience. Therefore, the third hypothesis in relation to economic status and financial resilience has also been accepted.

Regarding the household's economic status, data implies that the higher the household's economic condition, the respondents are more likely to be financially resilient. The findings also approve other relevant studies. For instance, in a study based in Sri Lanka, Asian Development Bank Institute (2004) states that poor people follow pawning to meet their emergency needs because they have no other option. The study also suggests that through financial inclusion, low-income households can address their day-to-day needs, adjust with their risks and undertake investment facilities which make them capable to expand their income and assets. Similarly, in another study conducted in Mexico, Eriksen et al. (2007), argue that poor people are not capable enough to meet their emergencies, such as a sick or dying family member, can plunge a family into crisis. They must borrow money although they are financially included.

According to CGAP (2000), poor people face a more vulnerable situation when they face various types of risks. They cannot handle easily the unexpected emergencies such as sickness or unwanted death of a family member and losing employment. But, Rutherford (2013) showed that financial inclusion (through micro-finance institutions) can play an effective role to manage risk and economic stress. 


\section{Hypothesis 4: Better saving patterns indicate more financial resilience}

Respondents who save (saving status during the three months preceding survey) money are more likely to be financially resilient than who do not save. After considering the socio-economic variables, the financial inclusion and saving pattern covariates are found to be significant predictors of the financial resilience. As we have seen before, the respondents having a financial account have around 1.4 times higher possibility to be financially resilient compared to respondents without financial accounts. Likewise, the respondents having savings are almost 3.0 times more likely to be resilient compared to respondents without savings (Table 1b). Therefore, the findings confirm the fourth hypothesis - better saving patterns improve financial resilience.

With savings patterns, the World Bank Findex dataset implies that the respondents having savings are almost three times more likely to be resilient compared to those without savings. A set of literature also supports these findings. Though it was not directly related to financial resilience, a study conducted by Brune et al. (2011) found that the increased financial access through saving accounts in rural Malawi improves the well-being of the poor households as they use savings for agricultural input and crisis management. In another research, CGAP (Consultative Group to Assist the Poor) found that financial services provide the means for poor households to transform small amounts of savings which work as a way of decreasing vulnerability in the long run. Based on digital savings accounts, the Women World Banking found in their study that savings accounts make women able to save money and use it in emergency needs. In another study which was based on a low-income area of Mexico City, Nino-zaruzua and Copestake (2008) found that the discipline of holding savings more securely control financial saving behavior which helps risk-prone respondents to cope with emergency sickness, loss of earnings or business failure (Nino-zaruzua and Copestake, 2008; McGuinness and Tounytsky, 2006), death of a family member (McGuinness and Tounytsky, 2006) and housings repairs (Nino-zaruzua and Copestake, 2008).

\section{Conclusions:}

Financial inclusion starts with having a bank account and its use. Shifting payments from cash into accounts play a significant role in a formal financial system, as it can improve the security and transparency of payments. This formal financial inclusion may lead to noteworthy increases in savings. Studies claim that people with savings are financially more resilient than their counterparts. Similar recommendations provided by the World Development Report in 2014 says that countries should attempt to encourage a wider use of financial tools not only for economic development but also to balance the broader policies to improve financial stability and increase financial resilience. Financial inclusion and access to finance are separate issues where many people have poor access to financial services due to barriers to use. But it is strongly believed that many barriers can be reduced by taking better policies. Financial inclusion offers people a safe place (financial institution) to save money and even provides access to credit when needed; as such people become able to manage risks (financial resilience). However, there is a gender gap in being financially resilient in Bangladesh; and even in intra-gender, the nature of risk-taking behavior is different. Because of gender, there is a significant association between gender and financial resilience where males enjoy better financial resilience than females. In intra-gender disaggregation, females with financial inclusion have more resilience control than females without financial inclusion. Therefore, regarding implications of financial inclusion on financial resilience, banks must increase financial services including mobile banking (where physical mobility of users is not significant) in unbanked areas and extend the 
volume of services to women and people who are out of reach. Because, often, people are not aware of all services; especially in rural areas. Another finding of this study acknowledges a positive and direct impact of education (more specifically, financial knowledge) on financial sustainability in need. These findings are useful for policy avenues to enhance financial inclusions by taking the targeted program for rural areas, low income and femaleheaded households and people with poor educational attainments. 


\section{References:}

Allen, H. 2002. CARE International's VS\&L Programme in Africa: Microfinance for the Rural Poor that Works.

Allen, H., and D. Panetta. 2010. Savings Groups: What Are They? Washington DC: The SEEP Network. Available at: http://www.pciglobal.org/downloads/SGsWhatAreThey.pdf accessed on 24 May 2013.

Allen, F., Demirgüc,-Kunt, A., Klapper, L., Peria, M.S.M. 2016. "The foundations of financial inclusion: understanding ownership and use of formal accounts.” Journal of Finance. In termed. (forthcoming).

Atkinson, A. and F. Messy .2013. "Promoting Financial Inclusion through Financial Education:

OECD/INFE Evidence, Policies and Practice”, OECD Working Papers on Finance, Insurance and Private Pensions, No. 34, OECD Publishing, Paris.

http://dx.doi.org/10.1787/5k3xz6m88smp-en

Asian Development Bank Institute. 2004. https://www.adb.org/document

Annual Financial Inclusion (AFI) annual report. 2016.

Bruhn, M., and I. Love. 2014. "The real impact of improved access to finance: evidence from Mexico." Journal of Finance 69 (3), 1347-1376.

Brune et al.2011.Commitments to Save: A Field Experiment in Rural Malawi, www. worldbank.org/DEC/Resources

Bernheim, B.D., \& Garrett, D.M. 2003. “The Effects of Financial Education in the Workplace: Evidence from a Survey of Households." Journal of Public Economics, 87(7/8), 1487-1519.

Chakma, N. 2013. The savings and investment behavior of extreme poor Marma community households in resilience building: a case study on Green Hill village savings and loan association intervention in the Chittagong Hill Tracts. Working Paper Number 19. Available at https://assets.publishing.service.gov.uk/media/57a089ee40f0b6497400031e/19-Eco Dev_final.pdf n

CGAP. 2000. The Consultative Group to Assist the Poorest: Focus on Poverty, 1818 H Street, NW Washington, DC 20433

Demirgüc, Kunt, A., Klapper, L. 2012. "Measuring Financial Inclusion. The Global Findex Database (Policy Research Working Paper No. 6025)." The World Bank, Washington, DC.

Demirgüc, Kunt, A., Klapper, L. and D. Singer. 2013. "Financial Inclusion and Legal Discrimination against Women: Evidence from Developing Countries.” Policy Research Working Paper No. 6416, The World Bank, Washington, DC.

Eriksen et al. 2007. Climate Change 2007 - Impacts, Adaptation and Vulnerability: Working Group 2, Contribution to the Fourth Assessment, Report of the Intergovernmental Panel on the Climate Change.

Han R. \& Melecky M. 2013. Financial inclusion for financial stability: access to bank deposits and the growth of deposits in the global financial crisis. World Bank Policy Research Working Paper No.6577. World Bank, Washington.

Hannig A. \& Jansen S. 2010. 'Financial inclusion and financial stability: current policy issues', ADBI Working Paper No. 259. Tokyo: Asian Development Bank Institute.

Hira, T.K., \& Cäzilia L. 2005. Understanding the Impact of Employer-provided Financial Education on Workplace Satisfaction. 39(1).

Holloway, K., Niazi, Z., \& Rouse, R. 2017. Women’s Economic Empowerment Through Financial Inclusion: A Review of Existing Evidence and Remaining Knowledge Gaps (Rep.). New Haven, CT: Innovations for Poverty Action 
International Labour Organization. 2011. - http://www.ilo.org/public

Kelegama S. 2014. Interview with Dr. Kelegama on Economic Outlook for 2014 in the Global Economy and Sri Lanka

Khalily et al. 2014. Access to financial services in Bangladesh, Institute of Microfinance, Bangladesh

Llanto, G. M. 2007. Policy and Regulatory Issues and Challenges in Micro-insurance: A Philippine Case. Philippine Journal of Development XXXIV(1): 61-86.

Lusardi, Annamaria, and Olivia S. Mitchell. 2006. Financial Literacy and Planning: Implications for Retirement Wellbeing. Working Paper, Pension Research Council, Wharton School, University of Pennsylvania.

McGuinness E. and Tounytsky V.2006. The Demand for Micro insurance in Pakistan, www.microfinanceopportunities.org

Muravyev, A., Scha“fer, D., \& Talavera, O. 2009. Entrepreneurs' gender and financial constraints: Evidence from international data. Journal of Comparative Economics, 37, 270-286.

Niño-Zarazua, M., \& Copestake, J. 2008. Financial inclusion, vulnerability, and mental models: From physical access to effective use of financial services in a low-income area of Mexico City. Savings and Development, 32(4), 353-379.

Ramji M. 2009. Financial Inclusion in Gulbarga: Finding Usage in Access, Institute for Financial Management and Research, Centre for Micro Finance, Working Paper Series No. 26

Rutherford S. 2013. A microcredit Crisis Averted: The Case of Bangladesh, CGAP.

Sharma, M. 2010. “Index of Financial Inclusion.” Discussion papers in Economics

Stephen et. al.2010. Poverty, Food Insecurity, and the Behavior for Childhood Internalizing and Externalizing Disorders, Journal of the American Academy of Child and Adolescent Psychiatry, Volume 49, Issue 5, Pages 444-452

World Bank. 2014. Global financial development report: Financial inclusion. Washington, DC: World Bank

World Development Report. 2014. Risk and Opportunity: Managing Risk for Development, http://econ.worldbank.org 


\section{Annex:}

Table 1a: Distribution of Respondents and their Financial Resilience Status (Multinomial)

\begin{tabular}{|c|c|c|c|c|c|c|c|}
\hline \multirow{2}{*}{$\begin{array}{l}\text { Background } \\
\text { Characteristics }\end{array}$} & \multirow[t]{2}{*}{$\begin{array}{l}\text { Number of } \\
\text { respondents (n) }\end{array}$} & \multicolumn{4}{|c|}{ Financially Resilient (\%) } & \multirow{2}{*}{$\begin{array}{c}\text { Chi- } \\
\text { squared } \\
\text { Value }\end{array}$} & \multirow{2}{*}{$\begin{array}{c}\text { p- } \\
\text { value }\end{array}$} \\
\hline & & $\begin{array}{c}\text { very } \\
\text { possible }\end{array}$ & $\begin{array}{c}\text { somewhat } \\
\text { possible }\end{array}$ & $\begin{array}{l}\text { not very } \\
\text { possible }\end{array}$ & $\begin{array}{l}\text { not at all } \\
\text { possible }\end{array}$ & & \\
\hline \multicolumn{8}{|c|}{ Has financial account (FA)? } \\
\hline Yes & 310 & 22.6 & 47.1 & 12.9 & 17.4 & \multirow{2}{*}{49.162} & \multirow{2}{*}{0.000} \\
\hline No & 683 & 10.2 & 38.2 & 19.2 & 32.4 & & \\
\hline \multicolumn{8}{|l|}{ Gender } \\
\hline Male & 508 & 15.7 & 42.5 & 19.5 & 22.2 & \multirow{2}{*}{16.863} & \multirow{2}{*}{0.001} \\
\hline Female & 485 & 12.4 & 39.4 & 14.8 & 33.4 & & \\
\hline \multicolumn{8}{|c|}{ Financial Account by Gender } \\
\hline Male with FA & 181 & 27.1 & 44.8 & 14.9 & 13.3 & \multirow{4}{*}{70.883} & \multirow{4}{*}{0.000} \\
\hline Female with FA & 130 & 16.9 & 50.0 & 10.0 & 23.1 & & \\
\hline Male without FA & 329 & 9.7 & 41.0 & 22.2 & 27.1 & & \\
\hline Female without FA & 355 & 14.2 & 40.9 & 17.3 & 27.6 & & \\
\hline \multicolumn{8}{|l|}{ Education Status } \\
\hline Secondary or higher & 492 & 21.1 & 45.3 & 16.1 & 17.5 & \multirow{2}{*}{76.257} & \multirow{2}{*}{0.000} \\
\hline Primary or less & 501 & 7.2 & 36.7 & 18.4 & 37.7 & & \\
\hline \multicolumn{8}{|c|}{ HH's Economic Status } \\
\hline Richest 20\% & 187 & 33.7 & 47.1 & 10.7 & 8.6 & \multirow{5}{*}{143.341} & \multirow{5}{*}{0.000} \\
\hline Fourth $20 \%$ & 198 & 11.6 & 48.0 & 18.2 & 22.2 & & \\
\hline Middle $20 \%$ & 203 & 13.3 & 43.8 & 15.3 & 27.6 & & \\
\hline Second $20 \%$ & 219 & 5.5 & 40.2 & 18.7 & 35.6 & & \\
\hline Poorest $20 \%$ & 188 & 8.0 & 25.0 & 23.4 & 43.6 & & \\
\hline \multicolumn{8}{|c|}{ Has any savings in the past year? } \\
\hline Yes & 238 & 24.4 & 52.5 & 9.7 & 13.4 & \multirow{2}{*}{67.197} & \multirow{2}{*}{0.000} \\
\hline No & 756 & 10.8 & 37.3 & 19.6 & 32.3 & & \\
\hline Total & 994 & 14.1 & 41.0 & 17.2 & 27.7 & - & - \\
\hline
\end{tabular}


Peer-reviewed version available at Development in Practice 2019; doi:10.1080/09614524.2019.1607256

Table 1b: Distribution of Respondents and their Financial Resilience Status (Binary)

\begin{tabular}{|c|c|c|c|c|c|c|}
\hline \multirow[b]{2}{*}{ Background Characteristics } & \multirow{2}{*}{$\begin{array}{l}\text { No. of respondents } \\
\text { (n) }\end{array}$} & \multirow{2}{*}{$\begin{array}{c}\text { Financially } \\
\text { Resilient }(\%)\end{array}$} & \multirow{2}{*}{$\begin{array}{l}\chi^{2} \text { Value } \\
\text { (p-value) }\end{array}$} & \multicolumn{3}{|c|}{ Binary Logistic Model } \\
\hline & & & & B & p-value & OR \\
\hline \multicolumn{7}{|l|}{ Has financial account (FA)? } \\
\hline Yes & 310 & 69.7 & \multirow{2}{*}{$38.79(0.000)$} & 0.359 & 0.031 & 1.432 \\
\hline No & 683 & 48.5 & & - & - & - \\
\hline \multicolumn{7}{|l|}{ Gender } \\
\hline Male & 508 & 58.3 & \multirow{2}{*}{4.257 (0.039) } & 0.360 & 0.011 & 1.433 \\
\hline Female & 485 & 51.8 & & - & - & - \\
\hline \multicolumn{7}{|l|}{ Financial Account by Gender } \\
\hline Male with FA & 181 & 71.7 & \multirow{4}{*}{$41.18(0.000)$} & & & \\
\hline Female with FA & 130 & 66.9 & & & & \\
\hline Male without FA & 329 & 50.8 & & & & \\
\hline Female without FA & 355 & 46.2 & & & & \\
\hline \multicolumn{7}{|l|}{ Education Status } \\
\hline Secondary or higher & 492 & 66.3 & \multirow{2}{*}{$49.65(0.000)$} & 0.680 & 0.000 & 1.975 \\
\hline Primary or less & 501 & 44.0 & & - & - & - \\
\hline \multicolumn{7}{|l|}{ HH's Economic Status } \\
\hline Richest $20 \%$ & 187 & 81.1 & \multirow{5}{*}{$98.53(0.000)$} & 1.799 & 0.000 & 6.043 \\
\hline Fourth $20 \%$ & 198 & 59.8 & & .943 & 0.000 & 2.567 \\
\hline Middle $20 \%$ & 203 & 57.4 & & .964 & 0.000 & 2.621 \\
\hline Second $20 \%$ & 219 & 45.7 & & .468 & 0.029 & 1.597 \\
\hline Poorest $20 \%$ & 188 & 32.8 & & - & - & - \\
\hline \multicolumn{7}{|c|}{ Has any savings in the past year? } \\
\hline Yes & 238 & 76.8 & \multirow{2}{*}{$59.29(0.000)$} & 1.012 & .000 & 2.751 \\
\hline No & 756 & 48.3 & & & & \\
\hline Total & 994 & 55.0 & - & 1.423 & .000 & .241 \\
\hline
\end{tabular}

